\title{
Technical and Economic Analysis of Aeroponics and other Systems for Potato Mini-Tuber Production in Latin America
}

\author{
Julian R. Mateus-Rodriguez • Stef de Haan • \\ Jorge L. Andrade-Piedra • Luis Maldonado • \\ Guy Hareau • Ian Barker • Carlos Chuquillanqui • \\ Victor Otazú • Rebeca Frisancho • Carolina Bastos • \\ Arione S. Pereira • Carlos A. Medeiros • \\ Fabian Montesdeoca - Jacqueline Benítez
}

Published online: 10 April 2013

(C) Potato Association of America 2013

\begin{abstract}
Producing large quantities of high quality minitubers at low cost is essential for an economically viable supply of seed potatoes. Here we systematize the technical and economic aspects of aeroponics and provide a benchmark comparison of this technology with other mini-tuber production systems as developed in Latin America: conventional, semi-hydroponics, and fiber-cement tiles technology. Research methodologies included: 3-year registration of cash flows and production registers of aeroponics, economic and technical surveys, in-depth inquiry with managers of technologies. Results show that aeroponics as promoted by
\end{abstract}

J. R. Mateus-Rodriguez

Tibaitatá Research Center, Corporación Colombiana de

Investigación Agropecuaria (CORPOICA), Mosquera, Colombia

S. de Haan $(\bowtie) \cdot$ L. Maldonado $\cdot$ G. Hareau $\cdot$ C. Chuquillanqui · V. Otazú $\cdot$ R. Frisancho $\cdot$ C. Bastos

International Potato Center (CIP), Avenida La Molina 1885,

La Molina, Lima 12, Peru

e-mail: s.dehaan@cgiar.org

\section{J. L. Andrade-Piedra}

International Potato Center (CIP),

P.O. Box 17-21-1977, Quito, Ecuador

I. Barker

Syngenta Foundation for Sustainable Agriculture,

Basel, Switzerland

\section{A. S. Pereira $\cdot$ C. A. Medeiros}

Empresa Brasileira de Pesquisa Agropecuaria (EMBRAPA),

Clima Temperado, Pelotas, RS, Brazil

F. Montesdeoca $\cdot$ J. Benítez

Instituto Nacional Autónomo de Investigaciones Agropecuarias

(INIAP), Santa Catalina Experimental Station, Quito, Ecuador the International Potato Center (CIP) has several advantages, including high multiplication rates (up to 1:45), high production efficiency per area ( $>900$ mini-tubers per $\mathrm{m}^{2}$ ), savings in water, chemicals and/or energy, and positive economic indicators. The fiber-cement tiles technology from Brazil is also shown to be highly efficient and slightly more robust compared to aeroponics. Preconditions for the successful adoption of the different technologies in developing countries are discussed.

Resumen La producción de grandes cantidades de minitubérculos de alta calidad y a bajo precio es esencial para un abastecimiento económicamente viable de semilla de papa. Aquí sistematizamos aspectos técnicos y económicos de aeroponía y se compara la línea de base de esta tecnología con otros sistemas de producción de mini-tubérculos que han sido desarrollados en América Latina: tecnología convencional, semi-hidroponía, tejas de fibrocemento. Metodologías de investigación incluyeron: registro de flujo de caja y registro de producción de aeroponía durante 3 años, encuestas económicas y técnicas, indagación en detalle con gerentes de tecnologías. Los resultados demuestran que la aeroponía tal como lo promueve el Centro Internacional de la Papa (CIP) tiene múltiples ventajas, entre ellas tasas altas de multiplicación (hasta 1:45), eficiencia alta de producción por área ( $>900$ minitubérculos por $\mathrm{m}^{2}$ ), ahorros en agua, químicos y/o energía, y indicadores económicos positivos. También se demuestra que la tecnología de tejas de fibrocemento de Brasil es muy eficiente y ligeramente más robusta comparada con aeroponía. Se discuten las condiciones previas para una adopción exitosa de las diferentes tecnologías en países en vía de desarrollo. 
Keywords Seed production system $\cdot$ Hydroponics . Semi-hydroponics $\cdot$ Fiber-cement tiles technology · Pre-basic tuber seed

\section{Introduction}

The vast majority of potato farmers in Latin America and in developing countries do not use certified seed. Various studies have singled out poor quality planting material as perhaps the single most important constraint undermining efforts to improve productivity (Ezeta 2001; Gildemacher et al. 2009a). In Latin America, with the exception of the southern cone (Chile, Argentina) and possibly Mexico, area planted using certified seed accounts for just a tiny fraction of total area planted. Informal seed systems are predominant in the Andean countries, particularly for the smallholder farmer provision of potato landraces (De Haan and Thiele 2004; Thiele 1999). Hidalgo et al. (2009) reported that the use of certified tuber seed in relation to all seed planted in Bolivia was $3.01 \%$ in 2005 and $2.37 \%$ in 2006. In Peru it was $0.34 \%$ in $2005,0.24 \%$ in 2006 and $0.46 \%$ in 2007. In Ecuador and Colombia, although updated data were not available, it is estimated that the use of certified tuber seed does not exceed $2 \%$. With the possible exception of India, the limited use of good quality planting material is similar in Asia (Jansky et al. 2009; Kadian et al. 1999), and even more so in much of Sub-Saharan Africa (Gildemacher et al. 2009b; Hirpa et al. 2010; Tripp 2006) with the exception of the Republic of South Africa (Niederwieser 2003).

National programs and development organizations in Latin America, Asia and Africa have spent decades trying to replicate the formal seed systems that exist for potatoes in the USA and northern Europe. Producing certified seed potatoes involves overcoming a complex combination of technical, ecological, institutional, and economic constraints. Taken together they typically result in a finished product that takes years to produce, is of dubious quality, prohibitively expensive or in extremely limited supply - or some combination of all four. One of the main economic problems of high quality seed tubers produced in formal systems in developing countries is their cost to the endusers. Such planting material can make up between 30 and $70 \%$ of the total production costs of a commercial crop (Struik and Wiersema 1999; Correa et al. 2009). The price of such seed preempts its use by the vast majority of limited-resource farmers that characterize the potato sub-sector in these countries. To relax this constraint, a common practice of many seed production programs is to produce the final seed (certified, authorized, or audited, depending on the legislation of each country) after three to five generations of propagation in the open field, in order to increase the volumes and reduce production costs, but at the risk of losing phytosanitary quality (Struik and Wiersema 1999).

Formal tuber seed production in Latin America, just as in many other parts of the world, usually has three multiplication stages. The first takes place in micro-propagation laboratories where in vitro seedlings or cuttings of high varietal purity and phytosanitary quality are produced. The second consists of the production of pre-basic seed in the form of mini-tubers in controlled environments (green- or screenhouses). The third stage involves taking the minitubers to the open field in order to increase volumes and obtain the basic seed and other categories of seed in accordance with each country's legislation. This model has undergone different modifications, resulting from technological development or the need to adapt it to situations that are peculiar to each production center (Ezeta 2001).

This article focuses on the technologies used for the second stage, i.e. the production of pre-basic seed or minitubers. Producing large quantities of high quality minitubers, at a low cost, in a relatively short period of time, and in an ecologically friendly manner is a key element for improving formal and non-conventional seed production systems (Camargo et al. 2004), i.e. alternative systems that follow rules, regulations and standards close to the formal system, but are better adapted to local realities and smallholder conditions. For example, the 3G Strategy (3 Generations, see Acronyms in Table 1) promoted by the International Potato Center (CIP). The core innovation of $3 \mathrm{G}$ consists of the production of large quantities of mini-tubers in a single generation using aeroponics. This makes it possible to produce final tuber seed after two generations in the field, instead of three to five generations. Seed tubers are sold to smallholder farmers who receive training to re-utilize the seed without compromising quality, e.g. through simple techniques such as positive selection and improved storage (Gildemacher et al. 2007, 2011). This strategy can also include the concept of Quality Declared Seed (FAO 2006), i.e. quality seed that is producer certified based on a decentralized quality control system.

The production of mini-tubers using soil substrates or a mixture of several solid compounds is widespread throughout Latin America. In vitro plantlets are normally directly transplanted to beds in green- or screenhouses. Soils are frequently extracted from vulnerable sites such as the high altitude páramo or puna ecosystems in Ecuador and Peru. Multiplication rates of these conventional or solid-substratebased systems are generally low (around ten mini-tubers per plant), which increases the production costs per unit. Moreover, the substrates are disinfested using heat or highly toxic products with significant negative impact on the environment and human health (Gullino et al. 2003).

An alternative technology for obtaining mini-tubers is hydroponics (Muro et al. 1997; Ranalli 1997; Rolot and 
Table 1 Acronyms and abbreviations

\begin{tabular}{|c|c|c|}
\hline $\begin{array}{l}\text { Acronym or } \\
\text { abbreviation }\end{array}$ & Meaning & Unit \\
\hline $3 \mathrm{G}$ & Three generations & \\
\hline$B / C$ & Benefit-cost ratio & Dimensionless \\
\hline$C$ & Unit cost of mini-tuber & US $\$$ per mini-tuber \\
\hline CIP & International Potato Center & \\
\hline CORPOICA & $\begin{array}{l}\text { Corporación Colombiana de Investigación Agropecuaria } \\
\text { [Colombian Agricultural Research Corporation] }\end{array}$ & \\
\hline EMBRAPA & $\begin{array}{l}\text { Empresa Brasileira de Pesquisa Agropecuária } \\
\text { [Brazilian Agricultural Research Enterprise] }\end{array}$ & \\
\hline GI & Gross income & US \$ per season \\
\hline INIA & $\begin{array}{l}\text { Instituto Nacional de Innovación Agraria } \\
\text { [National Institute of Agricultural Innovation] }\end{array}$ & \\
\hline INIAP & $\begin{array}{l}\text { Instituto Nacional Autónomo de Investigaciones Agropecuarias } \\
\text { [Autonomous National Institute for Agricultural Research] }\end{array}$ & \\
\hline$I R R$ & Internal rate of return & $\%$ \\
\hline NARI & National Agricultural Research Institute & \\
\hline NFT & Nutrient film technique & \\
\hline$N P$ & Net profit & US \$ per season \\
\hline$N P V$ & Net present value & US $\$$ \\
\hline Payback & Recovery of capital & Years \\
\hline$P$ & Profitability & $\%$ \\
\hline$Q$ & Quantity of mini-tubers produced & mini-tubers per season \\
\hline QDS & Quality declared seed & \\
\hline$T P C$ & Total production cost & US $\$$ per season \\
\hline
\end{tabular}

Seutin 1999). A specific technology belonging to the hydroponics family called telhas de fribrocimento (fiber-cement tiles) is based on the Nutrient Film Technique (NFT). The technology consists of a series of canals or tiles mounted on wooden supports, through which a film of nutrient solution flows to wet the roots of the plants (Medeiros et al. 2002). This type of hydroponics has been successfully developed in Brazil where it is applied by EMBRAPA (Factor et al. 2007; Correa et al. 2008).

Semi-hydroponics, also commonly referred to as passive hydroponics, is a specific application that consists of plants being grown in an inert medium that transports water and fertilizer to the roots by capillary action from a separate reservoir. This combination of solid substrates and hydroponics has also been adapted in the Andean region. In Colombia, the development of this technology has been the result of cooperation between the national agricultural research program (CORPOICA) and McCain (Laignelet and Villota 2006). In Ecuador, the national program (INIAP) developed a semi-hydroponics mini-tuber production scheme based on direct transplanting of in vitro plants into beds in a greenhouse.

One of the variants of hydroponics is aeroponics. With this technology the roots of the potato plant are inside a dark container exposed to a fine mist of a nutrient solution (Christie and Nichols 2004; Otazú 2010). Aeroponics has been used as a research tool (Tibbitts et al. 1996; Christie and Nichols 2004; Chang et al. 2008) and for mini-tuber production programs in Korea (Kang et al. 1996; Kim et al. 1997, 1999) and China (Sun and Yang 2004). Multiplication rates are reported to be significantly higher than those obtained in conventional systems, with less water and without the use of solid substrates (Soffer and Burger 1988; Ritter et al. 2001; Farran and Mingo-Castel 2006). Nichols (2005) emphasizes the potential of aeroponics for reducing at least one generation of seed multiplication in the field, with lower costs and maintaining high phytosanitary quality. Aeroponics has thus been adapted by CIP and national partners in Bolivia, Colombia, Peru, Ecuador, Ethiopia, Kenya, Uganda, and Malawi as part of the $3 \mathrm{G}$ strategy.

Recognizing that the economic and technical efficiency as well as the environmentally-friendly traits of any technology are a key factors for its dissemination and adoption, this article analyzes the principal economic and technical indicators of aeroponics adapted by CIP, as compared to other technologies for mini-tuber production developed and/or adapted in Brazil, Colombia, Ecuador, and Peru: conventional (solid-substrate-based), semi-hydroponics, and fiber cement tiles technologies. The aim of this research is to analyze the economics of setting up and operating these different technologies for producing mini-tubers in developing countries. 


\section{Materials and Methods}

\section{Selection of Technologies for Mini-Tuber Production}

The selection was based on information supplied by the national agricultural research programs that are members of the LatinPapa Network (Bastos et al. 2008). Table 2 shows the technologies that were selected for this study.

\section{Data-Gathering}

From 2008 to 2010, we recorded the fixed and variable costs of the aeroponics and conventional mini-tuber production technologies at the CIP experimental station of Santa Ana (Huancayo, Peru). In the case of aeroponics, this information was complemented with data from modules installed at two experimental stations of Peru's national agricultural research program (INIA) in the departments of Cajamarca and Junín. Detailed information of aeroponics in Ecuador, semi-hydroponics in Colombia and Ecuador, and fibercement tiles in Brazil was obtained from two surveys sent to specialists of each national program, using the same structure as that used for the Peru data. In-depth inquiry with managers of the technologies was conducted and the analyzed data was revised in detail.

\section{Technical Analysis}

Qualitative and quantitative variables were analyzed. Qualitative variables were as follows: existence of patents, degree of local adaptation (referring to whether there was some type of adaptation of the technology before starting up the production), ease of technology, requirement for equipment and inputs, water, solid substrate, disinfestation of substrates, qualified personnel, risk of total loss (due to pests, nutritional or equipment failures), health of minitubers harvested, and possibility of staggered harvests. Quantitative variables included: number of production cycles per year, greenhouses area $\left(\mathrm{m}^{2}\right)$, effective planting area $\left(\mathrm{m}^{2}\right)$, density (plants per $\mathrm{m}^{2}$ ), historical multiplication rate (per plant), historical average of mini-tubers per season and $\mathrm{m}^{2}$ per season.

\section{Cost Analysis}

First, a detailed cost analysis was conducted for the aeroponics technology as adapted by CIP in Peru (Tables 3 and 4). Based on this, a less detailed cost analysis was conducted for the rest of the technologies (Table 2). These analyses included production costs, and used several profitability indicators as described by Espinosa et al. (1996). Total production costs (TPC, US \$ per season) included fixed costs and variable costs. Fixed costs included the investment in infrastructure of green- or screenhouses and production modules, as well as materials and equipment. These costs were considered for a variable lifetime (years) and amortized during each agricultural season (Miragem et al. 1982). Variable costs included inputs of direct use: phytosanitary diagnoses, water, electricity, maintenance, storage, and personnel expenses.

\section{Economic Analysis}

For each technology, the cost of the mini-tuber ( $C$, US $\$$ per unit) was calculated using the formula $C=T P C / Q$, where $Q$ is the quantity of mini-tubers produced based on the records of historical production. For the calculation of gross income (GI, US \$) we used the sales value per mini-tuber as reported in the survey. The net profit (NP, US \$) was calculated according to Maldonado et al. (2007): $N P=G I$ $-T P C$. The profitability $(P)$ was obtained applying the formula $P=N P / T P C \times 100$.

With the information of the TPC, GI and NP, the cashflows were established, considering a productive activity of 7 years for each technology, including that of aeroponics (both in Peru and in Ecuador). The cash flow of the production activity, or the difference between income and expenditure, was used to define financial viability: net present value (NPV, US \$; Salas 1984), internal rate of return (IRR, \%; Vásquez et al. 2002), payback period (in years), and benefit-cost ratio (B/C; Gittinger 1982).

\section{Results}

\section{Technical Analysis}

Informants reported on the possibility of transferring and replicating these technologies using local materials, equipment and personnel. None of the technologies have any patents and all have been adapted locally. The difference related to the degree of or local adjustment (Table 2). The aeroponics and fiber-cement tiles technologies generally need a high degree of local adaptation, while the semihydroponics and conventional technologies require intermediate to modest levels of adaptation respectively. With regard to the aeroponics and fiber-cement tiles technologies, potential for replicability in developing countries can be relatively low in light of requirements for equipment, external inputs and specialized personnel to ensure effective operations. Semi-hydroponics is characterized by an intermediate degree of replicability because the use of solid substrates provides robustness. The conventional technology has a high degree of replicability.

With regard to requirements for equipment, materials and inputs, the greatest need exists for aeroponics and fiber- 


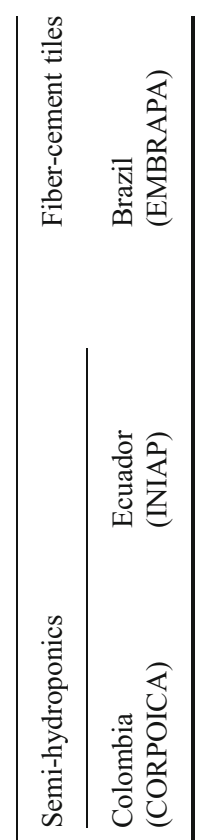

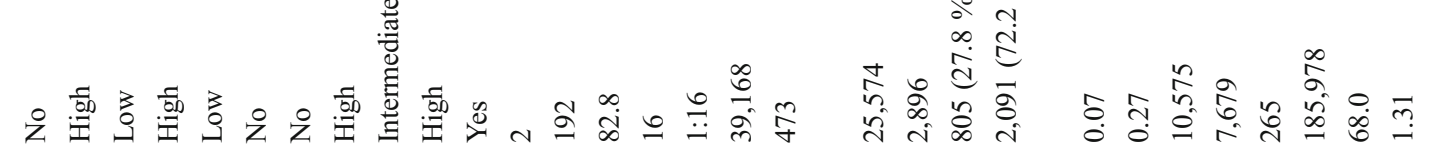

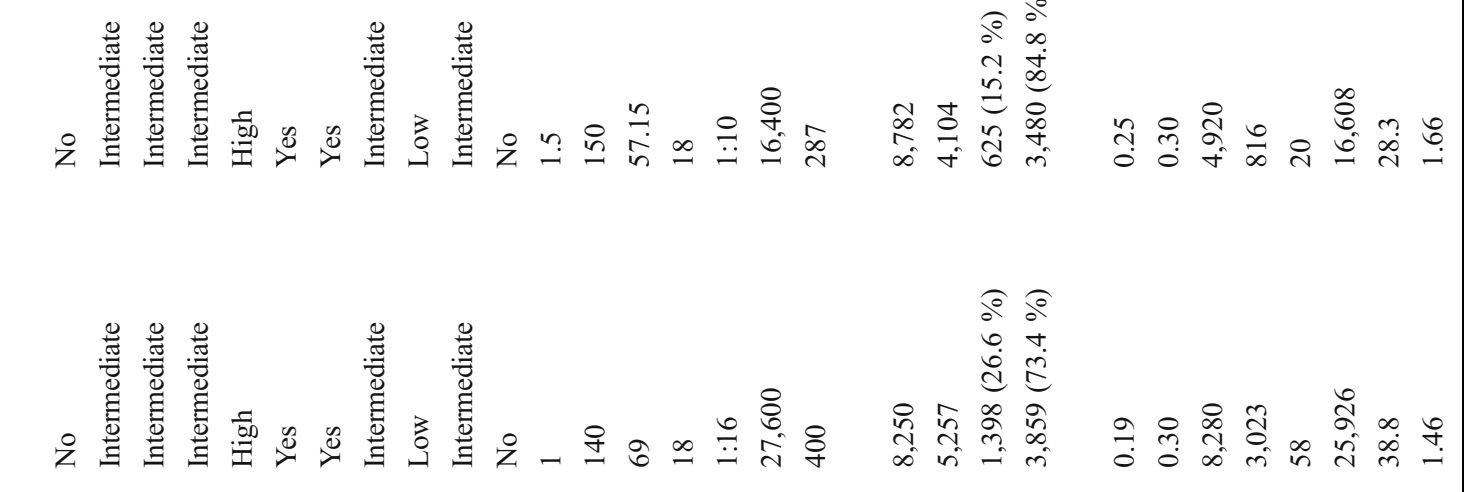

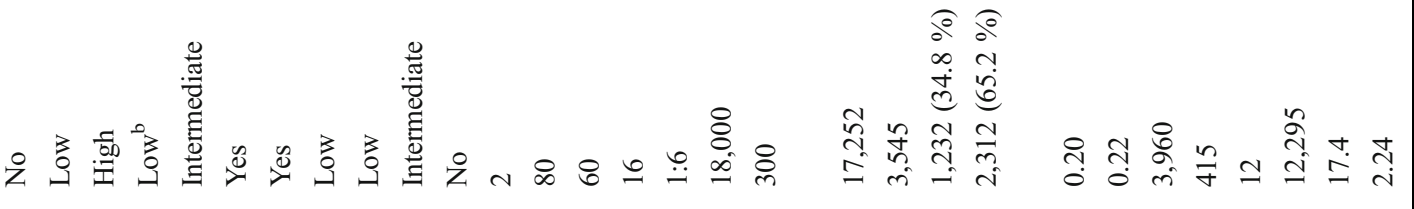

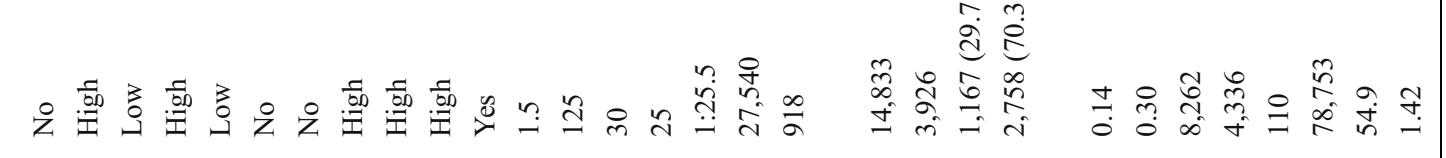
a

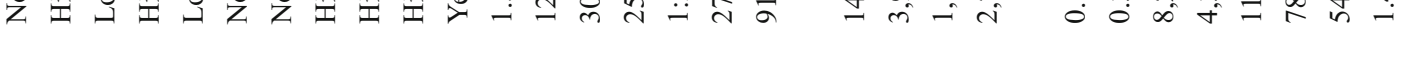

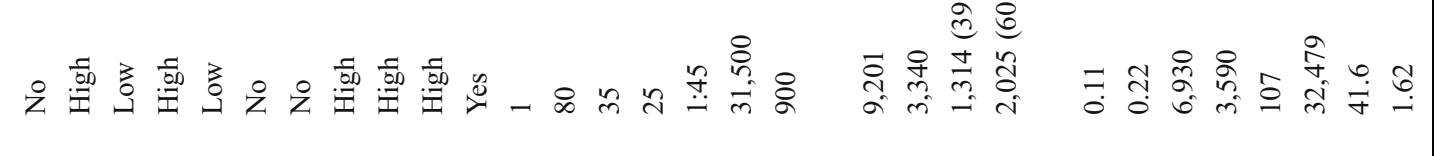
के $\frac{0}{9}$ 金

总 ब

E

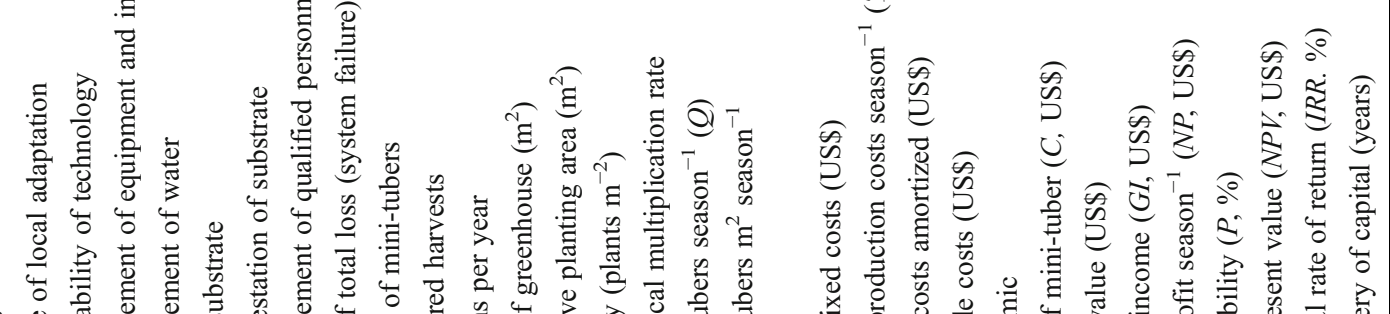

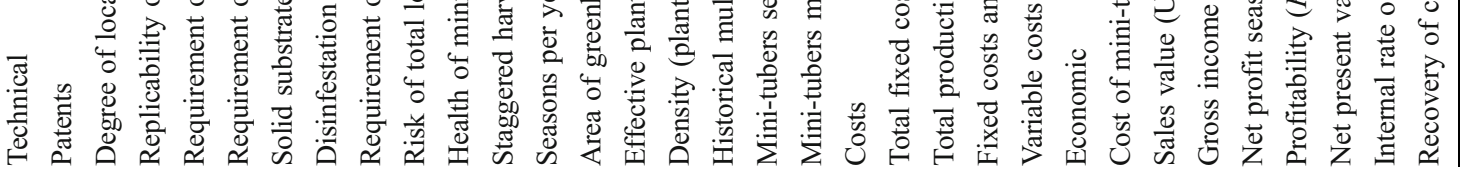




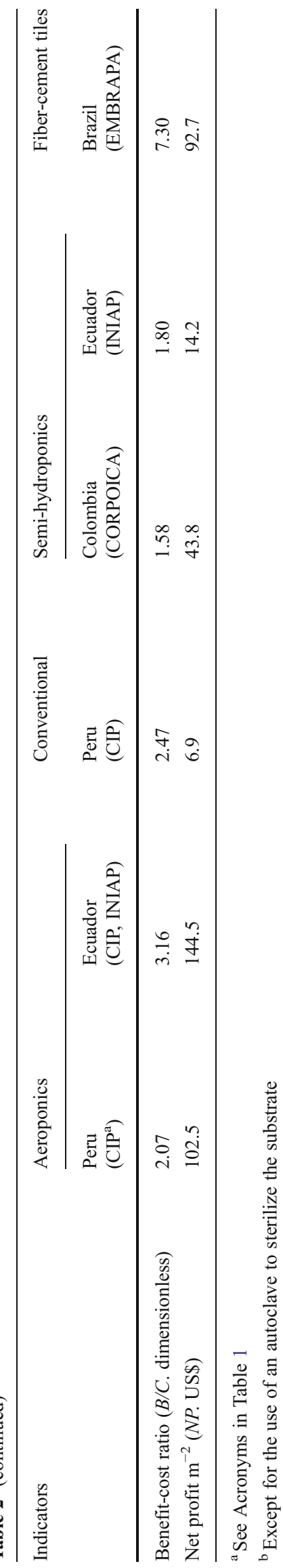

Table 3 Fixed costs for the implementation of an $80 \mathrm{~m}^{2}$ aeroponics system in Peru. January 2010

\begin{tabular}{|c|c|c|c|c|}
\hline Item & $\begin{array}{l}\text { Unit value } \\
\text { (US \$) }\end{array}$ & $\begin{array}{l}\text { Total value } \\
\text { (US \$) }\end{array}$ & $\begin{array}{l}\text { Value per } \\
\text { season (US \$) }\end{array}$ & $\%$ \\
\hline \multicolumn{5}{|l|}{ Initial infrastructure } \\
\hline Greenhouse & 4,720 & 4,720 & 674 & 94.0 \\
\hline $\begin{array}{l}\text { Watering system } \\
\text { housing }\end{array}$ & 300 & 300 & 43 & 6.0 \\
\hline Sub-total & & 5,020 & 717 & 54.5 \\
\hline \multicolumn{5}{|l|}{ Aeroponics module } \\
\hline Seed boxes & 1,665 & 1,665 & 238 & 45.6 \\
\hline Watering system & 1,019 & 1,019 & 146 & 27.9 \\
\hline Labor & 620 & 620 & 89 & 17.0 \\
\hline Drainage system & 345 & 345 & 49 & 9.5 \\
\hline Sub-total & & 3,650 & 521 & 39.6 \\
\hline \multicolumn{5}{|l|}{ Equipment } \\
\hline E.C. meter $^{\mathrm{a}}$ & 161 & 161 & 23 & 37.6 \\
\hline $\mathrm{pH}$ meter & 161 & 161 & 23 & 37.6 \\
\hline Sprinkler pump & 93 & 93 & 13 & 21.9 \\
\hline Thermometer & 12 & 12 & 2 & 2.8 \\
\hline Sub-total & & 426 & 61 & 4.6 \\
\hline \multicolumn{5}{|l|}{ Materials } \\
\hline Uniforms (3) & 15 & 45 & 6 & 42.4 \\
\hline Measuring cylinders & 20 & 20 & 3 & 19.0 \\
\hline Hose & 15 & 15 & 2 & 14.3 \\
\hline $\begin{array}{l}\text { Plastic applicator } \\
\times 500 \mathrm{ml}\end{array}$ & 8 & 8 & 1 & 7.7 \\
\hline Plastic recipients (5) & 1 & 7 & 1 & 7.0 \\
\hline Buckets & 5 & 5 & 1 & 4.8 \\
\hline Scissors & 5 & 5 & 1 & 4.7 \\
\hline Sub-total & & 105 & 15 & 1.3 \\
\hline Total & & 9,201 & 1,314 & 100.0 \\
\hline
\end{tabular}

${ }^{\mathrm{a}}$ Electrical conductivity

cement tiles, intermediate needs for semi-hydroponics, and relatively low needs for conventional technology, providing that the latter does not include the use of an autoclave for sterilization of the substrate. Regarding the use of water, high rates of efficiency were reported for aeroponics and fiber-cement tiles due to the re-use of the tank's nutrient solution, followed by the conventional technology with an intermediate requirement, and semi-hydroponics with a greater requirement. The later is a so-called open hydroponic system and these are typically characterized by the loss of nutrient solution. The conventional and semi-hydroponics technologies require the use of solid substrates. Therefore, the need for substrate sterilization only applies to these systems.

As far as personnel requirement are concerned (Table 2), the survey confirmed that the need for skilled and specialized operators is linked with the degree of complexity of each minituber production system. 
Table 4 Variable costs for one season of aeroponics production in an $80 \mathrm{~m}^{2}$ greenhouse in Peru. January 2010

\begin{tabular}{|c|c|c|}
\hline Item & Value per season (US\$) & $\%$ \\
\hline \multicolumn{3}{|l|}{ Inputs } \\
\hline Potato seedlings & 169 & 23.3 \\
\hline Electric energy & 169 & 23.3 \\
\hline Commercial nutrient solution & 143 & 19.7 \\
\hline Miscellaneous elements & 93 & 12.8 \\
\hline Chemical inputs & 90 & 12.4 \\
\hline Water & 33 & 4.5 \\
\hline Phytosanitary treatment & 15 & 2.1 \\
\hline Disinfectants & 13 & 1.8 \\
\hline Sub-total & 726 & 35.8 \\
\hline \multicolumn{3}{|l|}{ Diagnosis } \\
\hline Diagnosis of viruses & 54 & 78.3 \\
\hline Diagnosis of waters & 15 & 21.7 \\
\hline Sub-total & 69 & 3.40 \\
\hline \multicolumn{3}{|l|}{ Maintenance } \\
\hline Maintenance of equipment & 75 & 50.0 \\
\hline Maintenance of infrastructure & 75 & 50.0 \\
\hline Sub-total & 150 & 7.40 \\
\hline \multicolumn{3}{|l|}{ Cold Storage } \\
\hline Sub-total & 500 & 24.6 \\
\hline \multicolumn{3}{|l|}{ Personnel } \\
\hline Technical supervisor $^{\mathrm{a}}$ & 300 & 51.7 \\
\hline Operator & 280 & 48.3 \\
\hline Sub-total & 580 & 28.8 \\
\hline Total & 2,025 & 100.0 \\
\hline
\end{tabular}

${ }^{\text {a }}$ Salary of US $\$ 1,000$ per month. part-time ( $30 \%$ ) of his/her time

The highest level of expertise is required for aeroponics and fiber-cement tiles, followed by semi-hydroponics, and last conventional technology which can be operated by a technician with basic knowledge of crop management. Staggered harvests were only reported for aeroponics and fiber-cement tiles with up to six different moments of harvest per production cycle. One production cycle per year is obtained with aeroponics in Peru and semi-hydroponics in Colombia. One-and-a-half production cycle per year is common for aeroponics and semi-hydroponics in Ecuador. Two production cycles per year are reported for fiber cement tiles in Brazil and the conventional technology in Peru.

The possibility of total loss is highest for aeroponics, since there is no substrate at all (neither solid nor water) that would enable the plants to survive in the event of a technical failure or power cut. Fiber-cement tiles present an intermediate level of risk, since the root system will continue to be in contact with a thin film of water with nutrients in case of failure. For semi-hydroponics and conventional technologies, both of which use solid substrates, the risk of total loss is low. In the event of a technical failure, the solid substrate will still be able to maintain moisture for days. Even in the case of nutritional imbalance, this can be covered by the substrate itself. The highest standards of tuber seed health are obtained in aeroponics and fibercement tiles systems while technologies that use substrate generally show some degree of rejection of mini-tubers due to the presence of soil-borne pathogens.

Institutions reported different sizes of green- or screenhouses, effective planting areas and densities (Table 2). As for the historical multiplication rates (mini-tuber per plant), although these depend to a large extent on the varieties and the environment, informants indicated higher rates for the systems derived from hydroponics compared to those that use solid substrates. The highest production of mini-tuber per $\mathrm{m}^{2}$ per season was obtained with aeroponics, followed by fibercement tiles, hydroponics in Colombia, conventional technology in Peru and hydroponics in Ecuador.

\section{Cost Analysis}

The fixed costs of an aeroponics system in Peru amounted to $\$ 9,201$ (total) and $\$ 1,314$ per season (Table 3). These costs were estimated over a lifetime of 7 years and amortized to one season per year. They included the construction of an $80 \mathrm{~m}^{2}$ screenhouse with a plastic roof, concrete bases, wooden structure, anti-aphid mesh, and housing for the watering system, for a sub-total of $\$ 5,020(94.0 \%$ for the greenhouse). The cost of the actual aeroponics module amounted to a sub-total of $\$ 3,650$ with the highest participation being related to the construction of the boxes $(45.6 \%)$ and the watering system (27.9\%). The investments in other equipment amounted to $\$ 426$ and costs of materials totaled $\$ 105$.

The variable costs of aeroponics in Peru totaled $\$ 2,025$ per season (Table 4). The costs of inputs amounted to $\$ 726$ per season, of which $23.3 \%$ is related to the purchase of potato seedlings and $19.7 \%$ to the acquisition of the commercial nutrient solution. The energy and water costs account for approximately $27.8 \%$ of the costs of materials and inputs. This is relatively high due to the constant functioning of the watering pump which is required to maintain the moisture level in the boxes. Furthermore, the water has to be changed regularly (every 15 days), in order to maintain the ionic balance of the nutrient solution.

The diagnosis costs were $\$ 69$ per season while the maintenance of infrastructure and equipment amounted to $\$ 150$ per season. Aeroponics makes staggered harvesting possible, consequently enabling selections to be made by desired mini-tuber size and significant increasing the number of mini-tubers harvested per plant (Ritter et al. 2001). However, these staggered harvests cause differences of sprouting in the mini-tubers; it is therefore recommended to dry them in a dark environment at room temperature and 
subsequently store them at $4{ }^{\circ} \mathrm{C}$ (Farran and Mingo-Castel 2006). The consequent cost of cold storage of the minitubers averaged $\$ 500$. For the personnel, the cost of a technical supervisor part time (30\%) and a full-time operator was considered taking into account Peruvian standard wages (Table 4).

The TPC per season for the production of mini-tubers using aeroponics in the highlands of Peru was $\$ 3,340$ for a $80 \mathrm{~m}^{2}$ greenhouse (Table 2). The amortized fixed costs accounted for $39.4 \%$ of the TPC and the variable costs $60.6 \%$. A higher investment was made for the construction of the greenhouse and the aeroponics module in Ecuador $(\$ 14,833)$ compared to Peru. The TPC per season for aeroponics in Ecuador was slightly higher compared to the cost reported in Peru (\$586 difference). The TPC of aeroponics in Ecuador was calculated at $\$ 3,926$, of which $29.7 \%$ corresponded to fixed costs that were amortized during each season in accordance with the lifespan of the greenhouse (20 years), aeroponics module ( 5 years), and equipment and materials ( 3 years). The variable costs of aeroponics in Ecuador accounted for $70.3 \%$ of the TPC.

The conventional mini-tuber production technology in Peru had an initial investment of $\$ 17,252$ (Table 2). This amount was mostly due to the purchase of an autoclave for steam sterilization and the construction of a $80 \mathrm{~m}^{2}$ greenhouse. The highest variable costs were those of inputs, materials and personnel (data not shown). The TPC using conventional technology was $\$ 3,545$. Of this amount, $34.8 \%$ corresponded to fixed costs, amortized during each season in accordance with the useful lifetime of the autoclave, greenhouse, equipment and materials (7 years), while $65.2 \%$ corresponded to variable costs.

An initial investment of $\$ 8,250$ was reported for the semi-hydroponics technology in Colombia (Table 2). The main investments were made in the construction of a tunneltype greenhouse with an area of $140 \mathrm{~m}^{2}$, installation of seedbeds and purchase of the watering system. As for the variable costs, the greatest share was associated with inputs, materials and personnel costs. The TPC per season was calculated at $\$ 5,257: 26.6 \%$ fixed costs amortized in each production cycle (mostly for 7 years) and $73.4 \%$ associated with variable costs. The initial cost of the semi-hydroponics technology in Ecuador was $\$ 8,782$. This mainly consisted of the construction of a $150 \mathrm{~m}^{2}$ greenhouse and the installation of a watering system. Among the variable costs, the highest were those related to personnel, inputs, and materials. The $T P C$ per season for semi-hydroponics in Ecuador was calculated to be US $\$ 4,104$, of which $15.2 \%$ were associated with the fixed costs that are amortized over time (10-20 years for infrastructure, 7 years for the watering system, and 2 years for the seedbeds) and $84.8 \%$ were variable costs.

Finally, for the fiber-cement tiles technology in Brazil an initial investment of $\$ 25,574$ was reported (Table 2). The main investment was made in the fixed structure of the $192 \mathrm{~m}^{2}$ greenhouse, followed by the watering and drainage system, and equipment. As for the variable costs per season, the greatest share was associated with expenditure on personnel, inputs and materials. The calculated TPC per season was $\$ 2,896$, of which $72.2 \%$ was associated with variable costs and only $27.8 \%$ with fixed costs that were amortized during each season. The amortization periods in this case were longer than those reported above for the other minituber seed production systems, especially for the greenhouse (20 years), beds and supports (14 years), and the watering and drainage system (10 years), as well as the variability in the amortization of equipment and materials ( 8.5 years) and fiber cement tiles (6.5 years).

\section{Economic Analysis}

Table 2 shows the following performance indicators for each of the technologies: the mini-tuber production per season $(Q)$, mini-tubers $\mathrm{m}^{2}$ per season, the cost per mini-tuber $(C)$, sales value, and the estimation of $G I, N P, P, N P V, I R R$, payback period and $B / C$ ratio. In the case of aeroponics in Peru the average yield level was 45 mini-tubers per plant, depending on the variety. $Q$ was 31,500 mini-tubers in an $80 \mathrm{~m}^{2}$ screenhouse and $C$ was $\$ 0.11$ per mini-tuber. Assuming a sales value of $\$ 0.22$ per mini-tuber the GI per season would be $\$ 6,930$. The calculated $N P$ per season was $\$ 3,590$ and the profitability indicator $(P)$ was $107 \%$. Likewise, aeroponics in Ecuador reported $Q$ of 27,540 mini-tubers per season in a $125 \mathrm{~m}^{2}$ greenhouse with a production cost of $\$ 0.14$ per unit (Table 2). With the reported sales value of $\$ 0.30$ per mini-tuber we obtained a $G I$ of $\$ 8,262$, a $N P$ of $\$ 4,336$ and $P$ of $110 \%$. Profitability $(P)$ was very similar in both of the Andean countries.

Average production levels of the conventional solidsubstrate-based mini-tuber production technology in Peru resulted in a $Q$ of 18,000 mini-tubers in a $80 \mathrm{~m}^{2}$ screenhouse with a $C$ of $\$ 0.19$. With a sales value of $\$ 0.22$ we obtained a $G I$ of $\$ 3,960$ per season, a $N P$ of $\$ 41$ and a $P$ of $12 \%$. With semi-hydroponics in Colombia an average $Q$ of 27,600 mini-tubers was obtained in a $140 \mathrm{~m}^{2}$ greenhouse with a $C$ of $\$ 0.19$. An average sales value of $\$ 0.30$ per mini tuber was reported. On this basis, a $G I$ of $\$ 8,280$ per season was calculated with a $N P$ of $\$ 3,023$ and a $P$ of $58 \%$. In Ecuador, using the same technology, a $Q$ of 16,400 minitubers in a $150 \mathrm{~m}^{2}$ greenhouse was reported with a $C$ of $\$ 0.25$ (Table 2). Using the local sales value per mini-tuber of $\$ 0.30$ the calculated $G I$ was $\$ 4,920$, the $N P$ was $\$ 816$ and the $P$ per season was $20 \%$. Using the fiber-cement tiles technology in Brazil the $Q$ was 39,168 mini-tubers in a $192 \mathrm{~m}^{2}$ greenhouse with a $C$ of $\$ 0.074$. Taking into account the sales value in Brazil of $\$ 0.27$ per mini tuber the GI per season was $\$ 10,575$, the $N P \$ 7679$ and the $P 265 \%$. 
For each of the technologies positive $N P V$ 's were obtained with the highest $N P V$ for the fiber-cement tiles technology and the lowest $N P V$ for the conventional technology: $\$ 185,978$ and $\$ 12,295$ respectively. The IRR of the different systems showed a similar tendency with high values for the fiber-cement tiles technology followed by aeroponics, semi-hydroponics and finally conventional mini-tuber production. The difference in $N P V$ and $I R R$ values for the aeroponics technology in Ecuador as compared to Peru is largely explained by the number of seasons per year as allowed by local climate conditions. In all cases and the payback period was kept below 2 years with the exception of conventional technology which requires 2.47 years to achieve a return of the investment. The $B / C$ ratio was higher than 1 in all cases and particularly high for the fiber-cement tiles technology in Brazil followed by the aeroponics in Ecuador.

Finally, Table 2 enables a comparison of the technologies to be made in terms of the $N P$ per $\mathrm{m}^{2}$ per season. Using this indicator, aeroponics was the most profitable technology as it made it possible to obtain $N P$ values higher than $\$ 100$ per $\mathrm{m}^{2}$ per season. The fiber-cement tiles technology from Brazil resulted in a $N P$ value per $\mathrm{m}^{2}$ that was very close to the aeroponics technique in Peru. The semi-hydroponics technologies as implemented in Colombia and Ecuador showed considerable differences. This was due to the multiplication rate achieved in Colombia $(1: 16)$ versus Ecuador $(1: 10)$ and the related higher production cost per mini-tuber in Ecuador as compared to Colombia. With the conventional production technology a low $N P$ of $\$ 6.9$ per $\mathrm{m}^{2}$ per season was obtained.

\section{Discussion}

There is a direct relationship between the degree of complexity and efficiency of the technologies evaluated. Technologies that were more complex and demanding in expertise were also found to be more efficient in terms of their overall production output and economic performance. At the same time there is an inverse relationship between the degree of complexity and the robustness of the different mini-tuber production systems. The ability to withstand shocks, such as power or water cuts, is low for aeroponics and the fiber-cement tiles technology. The conventional solid-substrate-based technology is the least complex and certainly not as efficient as compared to the soilless systems. However, it is the most robust technology among the different systems compared. In general, depending on a country or region's context, different technologies that carefully balance efficiency and robustness must be sought. The type of users and prevalent socioeconomic conditions will determine the specific type technology to be recommended.
While the private sector and strong research programs such as EMBRAPA will mainly evaluate feasibility on the basis of efficiency, smallholder farmer organizations or resourcescarce national programs are likely to favor robustness over efficiency.

The technical and economic data from this study shows that the aeroponics technology as promoted by CIP shows some advantages over the other technologies: (i) high multiplication rates (1:25-1:45), (ii) high production efficiency per area (>900 mini-tubers per $\left.\mathrm{m}^{2}\right)$, (iii) savings in water, (iv) savings in chemicals or energy for substrate sterilization, (v) and phytosanitary quality of the mini-tubers. Aeroponics technology thus provides an interesting opportunity for an investor with a $P$ of more than $100 \%$ and an IRR above $40 \%$. These figures are based on several years of evaluation and more conservative compared to the pilotstage-level data shown by Maldonado et al. (2007) who compared aeroponics with conventional technology and reported a $P$ of up to $545 \%$ and an $I R R$ of $650 \%$.

The $B / C$ ratio is more than 2 and 3 for aeroponics in Ecuador and Peru respectively with a payback period of approximately a year-and-a-half for both countries. The initial investment in aeroponics infrastructure as embedded within the $T P C$ can be fairly high. However, equipment and infrastructure can be amortized over several years. The high multiplication rate of aeroponics is largely attributable to the staggered harvests, but also the type of genetic material used (Factor et al. 2007; Mateus-Rodríguez et al. 2012). A key factor in the success of aeroponics relates to the high minituber yields per plant and fixed surface area $\left(\mathrm{m}^{2}\right)$. These surpass yield levels of otherwise efficient technologies such as fiber-cement tiles. The average historical yield level of 45 mini-tubers per plant as registered for CIP's aeroponics system in Peru exceed those reported in Spain (12-13) and New Zealand (38) (Farran and Mingo-Castel 2006; Ritter et al. 2001; Nichols 2005). This is likely related to the use of a wider diversity of varieties, including Andigena type of materials. Aeroponics technology can likely result in quite different performance indicators if it were applied in durable housing conditions (20 years amortization), with Tuberosum type of materials and a production environment that allows for two production cycles per year.

Aeroponics technology does also have some significant disadvantages. First, relatively sophisticated watering equipment is required (sprinklers, pumps, timers, etc.). Often such equipment is not available in developing countries or needs to be imported. Second, it requires personnel qualified in plant nutrition, physiology and watering management. However, the main disadvantage resides in its limited robustness and the consequent risk of losing the entire production. The technology is sensitive to deficient water and energy supply, but also to diseases which are easily spread through the closed watering system. The entry of a vascular 
pathogen or a nutritional unbalance can cause irreversible damage to the plants within a few days (Farran and MingoCastel 2006). This sensitivity is also shared by the fibercement tiles technology. In Ecuador, during the validation phase of the aeroponics technology two out of three production cycles almost failed due to disease and nutrition related factors. Also in Peru several production cycles were cut short because of the same reason. Many of the practical sensitivities could be relatively easily solved if potato aeroponics experts from the world could share their practical expertise. However, mini-tuber production with aeroponics is typically a technology where advances have been made by the private sector and where information is commonly protected.

In Brazil the use of the fiber-cement tiles technology is very common for the production of potato mini-tubers and considered more economical and simpler than aeroponics (Correa et al. 2009). The technology has a low fixed cost per season because of the long amortization period for the greenhouse, material and equipment, as compared to those for aeroponics in Ecuador and Peru. However, the variable costs are approximately the same as those of the aeroponics technology (Table 2). Indeed the cost and durability of the housing of mini-tuber production systems is a main factor influencing economic performance. There is a huge difference between developing countries as for the type of materials and suppliers that are available. Often in countries with a flower industry access is easier and cheaper. Taking the previous considerations into account, the TPC per season of the fiber-cement tiles technology is lower than that of aeroponics. With low total costs per season, high sale values and two production seasons per year, this technology in Brazil shows outstanding indicators: (i) high net profit $(N P)$, (ii) high profitability $(P)$ (twice that of aeroponics), (iii) high $N P V, R R$ and $B / C$ ratios. The advantages and disadvantages of the fiber-cement tiles technology are similar to those of aeroponics However, the system is slightly more robust and yield levels are low compared to aeroponics with production records of 10 to 21 mini-tubers per plant, depending on the starting material (seedlings or tubers) and the cultivars used (Medeiros et al. 2002).

The semi-hydroponics technology in Colombia and Ecuador are characterized by a higher total production cost per season compared to the other systems studied due to the use of more inputs, particularly substrates for planting and chemicals for the sterilization process. Another variable influencing economic performance is the comparatively lower multiplication rate. These factors in turn raise the cost (C) per mini-tuber. For example, in Ecuador, the $C$ of a mini-tuber produce in semi-hydroponics is 1.8 times higher compared to the $C$ of mini-tubers obtained with aeroponics. The $P$ in Colombia and Ecuador, although positive, is lower than margins obtained with aeroponics or the fiber-cement tiles technology. This is also reflected in a lower IRR and $B / C$ ratio. Nevertheless, this technology does have some important advantages. It does not require highly qualified personnel or sophisticated equipment. In addition, the system is robust as it can maintain viable plants after several days without water and nutrients.

Conventional technology based on the use of solid substrates shows modest economic performance. This technology is still amply used by many tuber seed production programs in Latin America, even though yields are generally low with 6-8 mini-tubers per plant commonly being reported (Chuquillaqui et al. 2007). In many countries the price per cubic meter of substrate has steadily increased due to rising sterilization costs. A main difference between this technology and the others concerns the low multiplication rates per plant and $\mathrm{m}^{2}$. As in the case of the semihydroponics system, neither highly skilled personnel nor sophisticated equipment are required. In addition, the system is robust and can remain several days without water and nutrients. The $P$ and the $N P$ of the conventional system are positive. Further multiplication under open field conditions will likely further increase $P$ during subsequent cycles as the final return on investment for tuber seed production is often obtained from basic or certified seed rather than mini-tuber per se. Nevertheless, an increase in scale at the early stage of mini-tuber production through technologies such as aeroponics will positively impact on the final sales value of tuber seed from open field production and/or the phytosanitary quality of seed which can now be profitably produced in fewer generations; i.e.as proposed by CIP's $3 \mathrm{G}$ strategy.

Differences in the performance of the various technologies can also be partially explained by the type of varieties used (Andigena versus Tuberosum type) and production environment (climate). Both can affect the number of production cycles per year. In Peru with aeroponics, varieties of the Andigena type with relatively long vegetative periods have been used in a production environment where the temperature is a limiting factor: either low temperatures between June and August in the highlands of Huancayo at $3,200 \mathrm{~m}$ of altitude or high temperatures in the coastal dessert of Lima between January and March. Both environments only allow a single annual production cycle. By contrast, in Ecuador up to 1.5 cycles per year are reported with fairly late improved varieties such as Súper Chola and INIAP-Fripapa in a production environment where the annual fluctuation of temperature is modest compared to Peru (Santa Catalina research station, 3.060 m.a.s.l.). Mini-tuber production using the fiber-cement tile technology in Brazil is done with Tuberosum type varieties such as Agata, Asterix and Monalisa. Two cycles per year are possible under the prevalent environmental conditions of Brazil. Permanent mini-tuber production is only effective in 
combination with adequate storage and seed management practices that take into account the physiological age of based on staggered harvests.

Potato seed markets in developing countries tend to be imperfect. Demand for basic tuber seed is generally notably low after normal production seasons when certified seed is more widely available. A market for mini-tubers is near nonexistent in most countries. It is therefore common practice that mini-tuber producers scale-up their own mini-tuber production towards basic seed tubers. The size of operations and consequent economies of scale of mini-tuber production as well as the efficiency of open field production of minitubers and first-to-second generation seed tubers are factors that directly impact on the final price for end-users.

The benchmark study here reported provides evidence that aeroponics can be a valid option for developing countries if minimal conditions are met. It shows that aeroponics makes it possible to improve production efficiency and reduce costs compared with conventional methods or hydroponics-based techniques in Latin America. Aeroponics is a good option for national programs, private companies or other institutions with experience in minituber production under screen- or greenhouse conditions and with regular access to services, equipment and expertise. Aeroponics should not be recommended to producer organizations or institutions in countries with limited or irregular access to inputs. Other technologies and approaches might be more adequate for operations under basic conditions, i.e. the conventional or semi-hydroponics technologies in combination with practical management options such as positive selection (Gildemacher et al. 2011). Future research on technical aspects of aeroponics, particularly when centered on maximization of the production frontier beyond multiplication rates of $1: 45$, could be based on individualized management by variety (i.e. fertilization), controlled stress-management to induce tuberization, and optimized control of the growing environment.

Several recommendations can be made before considering the transfer of aeroponics to institutions with no or limited experience in hydroponics systems. First, allow a period of at least two cycles for validation and context specific adaptation of the technology. Second, support the implementing institution with technical backstopping in such fields as plant nutrition, physiology and pathology. Finally, initially combine the aeroponics system with other technologies as to prevent loss or reduction of production output in case of problems or even collapse. These recommendations are valid at the initial or start-up stage of the technology. Furthermore, it has to be taken into account that mini-tuber production technologies represent just one critical step in the potato tuber seed production pipeline. Without the prior provision of healthy starting materials (invitro plantlets or cuttings) or posterior adequate management under open field conditions the technology will not unleash its full potential. Data presented here shows that fiber-cement tiles are also an excellent option for producing potato mini-tubers with slightly less risk compared to aeroponics. South-south exchange of knowledge and expertise might facilitate further testing, adaption and dissemination of this technology within Latin America and sub-Saharan African countries.

Acknowledgments This research was conducted with funding from INIA Spain and FONTAGRO under the umbrella of the LatinPapa Network project. The authors acknowledge the valuable feedback from specialists from Colombia, Ecuador, Peru and Brazil.

\section{References}

Bastos, C., S. de Haan, and M. Bonierbale. 2008. Red Iberoamericana de innovación en mejoramiento y diseminación de la Papa - Red LatinPapa. In XXIII Congreso de la Asociación Latinoamericana de la Papa y VI seminario Latinoamericano de uso y comercialización de la Papa, ed. F. Lucca, 160-161. Argentina: Mar de Plata.

Camargo, C.P., C. Bragantini, and A. Monares. 2004. Small-scale farmers' seed production systems: a non-conventional approach. In Seed multiplication by resource-limited farmers, ed. FAO, 6366. Rome, Italy: Food and Agriculture Organization of the United Nations (FAO). Plant Production and Protection Paper 180.

Chang, D.C., C.S. Park, S.Y. Kim, S.J. Kim, and Y.B. Lee. 2008. Physiological growth responses by nutrient interruption in aeroponically grown potatoes. American Journal of Potato Research 85: 315-323.

Christie, C.B., and M.A. Nichols. 2004. Aeroponics: a production system and research tool. Acta Horticulturae 648: 185-190.

Chuquillaqui, C., J. Tenorio, and L.F. Salazar. 2007. Producción de semilla de papa por hidroponía. In Alternativas al Uso del bromuro de metilo para la producción de semilla de papa de calidad, ed. CIP, 26-34. Lima, Peru: International Potato Center (CIP). Integrated Crop Management Division Working paper.

Correa, R.M., J.E.B. Pinto, C.A.B.P. Pinto, V. Faquin, E.S. Reis, A.B. Monteiro, and W.E. Dyer. 2008. A comparison of potato seed tuber yields in beds, pots and hydroponic systems. Scientia Horticulturae 116: 17-20.

Correa, R.M., J.E.B. Pinto, V. Faquín, C.A.B.P. Pinto, and E.S. Reis. 2009. The production of seed potatoes by hydroponic methods in Brazil. Fruit, Vegetable and Cereal Science and Biotechnology 3(1): 133-139.

De Haan, S., and G. Thiele. 2004. In-situ conservation and potato seed systems in the Andes. In Seed systems and crop genetic diversity on-farm, ed. I. Jarvis, R. Sevilla-Panizo, J.L. Chavez-Servia, and T. Hodgkin, 126-132. Rome: International Plant Genetic Resources Institute (IPGRI). proceedings of a workshop (Pucallpa, Peru, 16-20 September 2003).

Espinosa, P., C.C. Crissman, and A. Hibon. 1996. Accounting for seed potato production costs: a computer spreadsheet-based management tool. Lima: International Potato Center (CIP). Training manual.

Ezeta, F.N. 2001. Producción de semilla de papa en Latinoamérica. Revista Latinoamericana de la Papa 12: 1-14.

Factor, T.L., J.A.C. Araujo, F.P.C. Kawakami, and V. Iunck. 2007. Produção de minitubérculos básicos de batata em três sistemas hidropônicos. Horticultura Brasileira 25: 82-87. 
FAO. 2006. Quality declared seed system. FAO Plant Protection and Protection Paper 185.

Farran, I., and A.M. Mingo-Castel. 2006. Potato mini-tuber production using aeroponics: effects of plant density and harvesting intervals. American Journal of Potato Research 83: 47-53.

Gildemacher, P., P. Demo, P. Kinyae, M. Wakahui, M. Nyogensa, and T. Zschocke. 2007. Select the best: positive selection to improve farm saved seed potatoes - trainers manual. Lima: International Potato Center (CIP).

Gildemacher, P.R., W. Kaguongo, O. Ortiz, A. Tesfaye, G. Woldegiorgis, W. Wagoire, R. Kakuhenzire, P. Kinyae, M. Nyongesa, P. Struik, and C. Leeuwis. 2009a. Improving potato production in Kenya, Uganda and Ethiopia: a system diagnosis. Potato Research 52: 173-205.

Gildemacher, P.R., W. Kaguongo, P. Demo, I. Barker, G. Woldegiorgis, W.W. Wagoire, M. Wakahiu, C. Leeuwis, and P.C. Struik. 2009b. A description of seed potato systems in Kenya, Uganda and Ethiopia. American Journal of Potato Research 86: 373-382.

Gildemacher, P., E. Schulte-Geldermann, D. Borus, P. Demo, P. Kinyae, P. Mundia, and P. Struik. 2011. Seed potato quality improvement through positive selection by smallholder farmers in Kenya. Potato Research 54: 253-266.

Gittinger, J. 1982. Análisis económico de proyectos agrícolas. Second edition. Editorial Tecno S.A., Madrid, Spain: International Bank for Reconstruction and Development (IBRD), World Bank.

Gullino, M.L., A. Camponogara, G. Gasparrini, V. Rizzo, C. Clini, and A. Garibaldi. 2003. Replacing methyl bromide for soil disinfestation. Plant Disease 87: 1012-1021.

Hidalgo, O., K. Manrique, C. Velasco, A. Devaux, and J.L. AndradePiedra. 2009. Diagnostic of seed potato systems in Bolivia, Ecuador and Peru focusing on native varieties. In Proccedings of the 15th international symposium of the international society for tropical root cropsed, ed. ISTRC, 41-46. Peru: Lima.

Hirpa, A., M.P.M. Meuwissen, A. Tesfaye, W.J.M. Lommen, A. Oude Lansink, A. Tsegaye, and P.C. Struik. 2010. Analysis of seed potato systems in Ethiopia. American Journal of Potato Research 87: 537-552.

Jansky, S.H., P.P. Jin, K.Y. Xie, C.H. Xie, and D.M. Spooner. 2009. Potato production and breeding in China. Potato Research 52: 57-65.

Kadian, M.S., S.G. Ilangantileke, U. Jayasinghe, A.E. Hossain, M. Hossain, and A.G.C. Babu. 1999. Potato seed systems in Bangladesh and Sri Lanka. Potato, Global Research and Development. Proceedings of the Global Conference on Potato. December 6 to 11, 1999. New Delhi, India.

Kang, J.G., S.Y. Kim, H.J. Kim, Y.H. Om, and J.K. Kim. 1996. Growth and tuberization of potato (Solanum tuberosum L.) cultivars in aeroponics, deep flow technique and nutrient film technique culture Systems. Journal of Korean Society for Horticultural Science 37: 24-27.

Kim, K.T., S.B. Kim, S.B. Ko, and Y.B. Park. 1997. Effect of minituber picking intervals on the yield and tuber weight of potato grown in aeroponics. RDA Journal of Horticulture Science 39: 65-69.

Kim, H.S., E.M. Lee, M.A. Lee, I.S. Woo, Y.B. Moon, and S.Y. Kim. 1999. Production of high quality potato plantlets by autotrophic culture for aeroponics systems. Journal of Korean Society for Horticultural Science 40: 26-30.

Laignelet, A., and C. Villota. 2006. Los modelos de innovación: tecnologías al alcance de los productores. Revista de Innovación y Cambio Tecnológico 4(2): 3-6.
Maldonado, L., G. Thiele, and V. Otazú. 2007. Análisis de costos entre el sistema convencional de producción de semilla de papa de calidad y el sistema de aeroponía. In Alternativas al uso del bromuro de metilo para la producción de semilla de papa de calidad, ed. CIP, 46-53. Lima: International Potato Center (CIP). Integrated Crop Management Division Working paper.

Mateus-Rodríguez, J., S. de Haan, I. Barker, C. Chuquillanqui, and A. Rodríguez-Delfín. 2012. Response of three potato cultivars grown in a novel aeroponics system for mini-tuber seed production. Acta Horticulturae 947: 361-367.

Medeiros, C.A., A.H. Ziemer, J. Daniels, and A.S. Pereira. 2002. Produção de sementes prébásicas de batata em sistemas hidropônicos. Horticultura Brasileira 20(1): 110-114.

Miragem, S., F. Nadal, N. Fuentes, J. Porteiro, E. Pietra, B. Sánchez, and R. Platero. 1982. Guía para la elaboración de proyectos de desarrollo agropecuario, Serie Desarrollo Institucional. San José: Inter American Institute for Cooperation on Agriculture (IICA).

Muro, J., V. Díaz, J.L. Goni, and C. Lamsfus. 1997. Comparison of hydroponic culture and culture in a peat/sand mixture and the influence of nutrient solution and plant sensity on seed potato yields. Potato Research 40: 431-438.

Nichols, M.A. 2005. Aeroponics and potatoes. Acta Horticulturae 670: 201-206.

Niederwieser, J.G. 2003. Guide to potato production in South Africa. Pretoria: ARC-Roodeplaat Vegetable \& Ornamental Plant Institute.

Otazú, V. 2010. Manual on quality seed potato production using aeroponics. Lima: International Potato Center (CIP).

Ranalli, P. 1997. Innovative propagation methods in seed tuber multiplication programmes. Potato Research 40(4): 439-453.

Ritter, E., B. Angulo, P. Riga, J. Herrán, J. Relloso, and M. San José. 2001. Comparison of hydroponic and aeroponic cultivation systems for the production of potato mini-tubers. Potato Research 44: 127-135.

Rolot, J.L., and H. Seutin. 1999. Soilless production of potato minitubers using a hydroponic technique. Potato Research 42: 457469.

Salas, W. 1984. Factibilidad de los proyectos agropecuarios. San Jose: Editorial Tecnológica de Costa Rica.

Soffer, H., and D.W. Burger. 1988. Effects of dissolved oxygen concentration in aeroponics on the formation and growth of adventitious roots. Journal of the American Society for Horticultural Science 113: 218-221.

Struik, P.C., and S.G. Wiersema. 1999. Seed potato technology. Wageningen: Wageningen University Press.

Sun, H.S., and Y.J. Yang. 2004. Seed potato production in China. In Proceedings of the fifth world potato congress, ed. WPC, 182186. Yunnan: Yunnan Fine Arts Publishing House.

Thiele, G. 1999. Informal potato seed systems in the Andes: why are they important and what should we do with them? World Development 27: 83-99.

Tibbitts, T.W., J.G. Croxdale, C.S. Brown, and R.M. Wheeler. 1996. Growing potato tubers in space. HortScience 31(4): 607.

Tripp, R. 2006. Strategies for seed system development in sub-Saharan Africa: a study of Kenya, Malawi, Zambia and Zimbabwe. SAT Journal 2(1): 5-50.

Vásquez, E., E. Aramburú, C. Figueroa, and C. Parodi. 2002. Gerencia Social: diseño, monitoreo y evaluación de proyectos sociales. Lima: Universidad del Pacífico Research Center (CIUP). 